\title{
AIR TRANSPORT IN TRANS-EUROPEAN TRANSPORT NETWORK
}

\author{
Dariusz KOMPAŁA, M.A. \\ National Defence University, Warsaw, Poland
}

\begin{abstract}
Air transport has become a more popular means for transporting people and goods, mainly due to the characteristics of air transport. Member states of the European Union decided to set up the Trans-European Transport Network to improve the speed of movement of goods and people as well as the quality of infrastructure. Particularly noteworthy is air transport, which is one of the fastest means of transport in the world.
\end{abstract}

The aim of this publication is to present air transport in the Trans-European Network and show how this affects Poland.

Keywords: air transport, Trans-European Transport Network

\section{Introduction}

The single European transport network should be an essential tool for achieving freedom of movement of people and goods throughout the European Union. On the one hand to ensure territorial groups, on the other - to facilitate business and labour mobility. In practice, there are still significant disparities in the development of transport infrastructure between the European Union member states, especially between countries that jointly created the Union before 2004 and those who joined later.

The aim of this publication is to present air transport in the Trans-European Transport Network and show how this affects Poland. 


\section{General information}

The concept of the Trans-European Network (TEN) dates back to the 1980s, when the European Community was working on a project to create a single market. The purpose of its creation was to support the existing four freedoms on the basis of a modern and efficient infrastructure. The Trans-European Network includes transport, energy and telecommunications infrastructure ${ }^{1}$.

The confirmation of the importance of this concept for the Progress of European integration is the dedication of a separate title in the Treaty of Maastricht. In accordance with article 129b, point 1 of the Treaty (...) to enable the citizens of the Union, economic operators and regional and local communities to derive full benefit from the establishment of an area without internal frontiers, the community shall contribute to the establishment and development of Trans-European Networks in the areas of transport, telecommunications and energy ${ }^{2}$.

Trans-European Networks are considered to be a part of the concept of the PanEuropean Transport Network, which dates back to the 1991 when Prague hosted the first of the three Pan-European Transport Conferences (the second was in Crete in 1991 and the third was in Helsinki in 1997).

The implementation of the Trans-European Transport Network and managing the technical and financial responsibility lies with the Trans-European Transport Network Executive Agency (TEN-T EA). It has an important role to undertake tasks until 31 December 2015. Its tasks are to manage major projects in the field of transport infrastructure in accordance with the financial perspective for the years $2000-2006$ and $2007-2013$. This is done in close cooperation with the Directorate-General for Mobility and Transport of the European Commission (DG MOVE), which is still responsible for the overall Policy, programming and evaluation of the Trans-European Transport Network ${ }^{3}$.

1 http://www.ulc.gov.pl/index.php?option=com_content\&task=view\&id=322\&Itemid=3 33, [01.02.2015].

2 Article 129b, point 1 of the Treaty of Maastricht.

3 http://europa.eu/agencies/executive_agencies/ten-t/index_pl.htm, [01.02.2015]. 
As regards the legal basis, the Trans-European Network Title XV of The Treaty of European Union (TEU).came into force in November 1993, the European Community did not have a clear legal basis to be able to initiate a transport infrastructure project which would be in the interest of all members of the community. Pursuant to the provisions contained in Article 154 of the Treaty of European Union, these networks are designed to contribute to the smooth operation and development of the internal market and to ensure economic, social and territorial cohesion*.

European Union action should be aimed at promoting the interconnection and interoperability that national networks provide. In addition, measures should ensure access to these networks as much as possible with particular emphasis on the connection of peripheral regions, closed and insular regions with the central regions of the European Union.

In accordance with the objectives set, the Community in Article 155 of the Treaty of European Union establishes a set of guidelines, which include the objectives, priorities and broad line of action which should place special emphasis on the common interests pursued by the member states. These projects are defined in the community guidelines - Decision No 1692/96 on the development of TransEuropean Transport Network. It is valid to this day, as amended by Decision No 1346/2001 and Decision No 884/20045.

By virtue of these decisions, the Trans-European Transport Network is created in stages with integration of the network infrastructure of road, rail, maritime highways, ports and inland shipping, air transport and other interconnection points between networks in the European Union. The assumption for 2020 is the planned completion of the 30 priority objectives. The guidelines, which closely relate to the transport network, must be reviewed every five years in order to adapt them in the best way for the changes that are constantly taking place in the technology and business development in the transport sector.

4 Article 154 of the Treaty of European Union.

5 http://www.cie.gov.pl/HLP/files.nsf/0f93de09147035b3c1256ef5004250b8/ 782f3a4858c8d510c125733900445df2?OpenDocument, [01.02.2015]. 
The main tasks of the Trans-European Transport Network include ${ }^{6}$ :

- ensuring the mobility of people and goods within the European Union,

- contributing to the strengthening of economic and social cohesion,

- offering very high quality infrastructure,

- embracing all forms of transport,

- enabling optimum use of capacity,

- interoperability and encouraging the intermodal between different modes of transport,

- economic viability,

- covering the entire territory of the member states of the European Union,

- ability to connect to the EFTA networks, central and Eastern Europe and the countries of the Mediterranean Basin.

The Trans-European Network includes transport infrastructure (including airports), traffic management systems and positioning and navigation systems (necessary technical installation and information and telecommunications systems).

\section{Air transport and Trans-European Transport Network}

Air Transport in the Trans-European Transport Network based on the decision contained in Decision No 1692/1996 on community guidelines for the Development of the Trans-European Transport Network. Regarding air transport, there are two Decision No 1346/2001 and 884/2004, which relate closely to that area.

The Trans-European Airport Network consists of airports located in the European Union, which have the ability to perform commercial flights and meet one of the criteria listed below ${ }^{7}$ :

1. International connecting points will include all airports or airports systems with an annual traffic volume of not less than:

6 http://europa.eu/agencies/executive_agencies/ten-t/index_pl.htm, [03.02.2015].

7 http://www.ulc.gov.pl/index.php?option=com_content\&task=view\&id=322\&Itemid=3

33, [03.02.2015]. 
a. 5000000 passenger movements ${ }^{8}$ minus $10 \%$,

b. 100000 commercial flights ${ }^{9}$,

c. 150000 tons of cargo transported,

d. 1000000 passenger movements outside the Community or any new airport constructed to replace an existing international connecting point which cannot be developed further in this way.

2. Community connecting points will include all airports and airports systems with an annual traffic volume:

a. between 1000000 minus $10 \%$ and 4499999 passenger movements,

b. between 50000 and 149999 tons of cargo,

c. between 500000 and 899999 passenger movements, of which at least $30 \%$ are non national,

d. between 300000 and 899999 passenger movements and located off the European mainland at a distance of over $500 \mathrm{~km}$ from the nearest international connecting point,

e. any new airport constructed to replace an existing international connecting point which cannot be developed further in this way.

3. Regional nodes and access points will include all airports:

a. with an annual traffic volume of between 500000 and 899999 passenger movements, of which less than $30 \%$ are non national,

b. with an annual traffic volume of between 250000 minus $10 \%$ and 499999 passenger movements,

c. with an annual traffic volume of between 10000 and 49999 tons of cargo,

d. located on an island of a member state,

e. located in an area of the community without access to the sea ${ }^{10}$ with commercial services operated by aircraft with a maximum loading of more than 10 tons.

The role of airports in the Trans-European Transport Network is universally recognized as the development of flights and ensuring internal connections

8 Passenger movement - passenger traffic within the meaning of the amount of passengers served.

9 Commercial flights - understood as commercial flights in accordance with the Polish Air Law.

10 The Airport is located in an area without access to the sea if it is located within a radius of over $100 \mathrm{~km}$ from the nearest international or community connecting point. This distance may be exceptionally reduced to $75 \mathrm{~km}$, taking into account the difficult access to the port due to the geographical situation or the poor quality of the inland transport infrastructure. 
exist between air transport and other modes of transport. As a basis, the TransEuropean Air Network considered international and community connecting points that are to be designed to provide support for connections between the European Union and the rest of the world.

Region points also have to facilitate the use of the network and provide communication with peripherals as well as hard to access regions.

The above mentioned international and community connecting points should be combined with the help of a gradual process, with a rapid rail network wherever it is possible. The Trans-European Transport Network should consist of facilities enabling the integration of air transport to rail, and in some cases even to the sea.

\section{Air Transport Management Network in Trans-European Transport Network}

The Trans-European Air Traffic Management Networks control the airspace which is reserved for general aviation, air navigation aids, air routes, planning and traffic management systems and the air traffic control systems (devices used for surveillance and communications, control centre) which are considered as a factor necessary for safe and efficient aviation in European airspace ${ }^{11}$.

Projects that have a chance of recognition in the category of common interest must lead to increased efficiency of the system and to optimise its use. They represent part of the harmonising and integrating factors, equipment and procedures for different types of national calls. In addition, they must fulfil standards specified by the International Civil Aviation Organisation (ICAO) and other organisations involved in the evolution of security standards designed to ensure the highest possible level of safety. The above conditions also include the guidelines of EUROCONTROL.

11 http://europa.eu/agencies/executive_agencies/ten-t/index_pl.htm, [05.02.2015]. 
The above mentioned projects, in particular, should related to ${ }^{12}$ :

- studies on better utilisation of airspace by various users including the creation of a coherent and efficient system of routes,

- improving the efficiency of the system, focusing on automated control systems and resolving and detecting potential threats,

- use of communications, navigation and tracking necessary for air traffic control, including the promotion of new technologies, especially digital networks and satellite,

- managing and planning air traffic to help meet the demand, and in addition allowing optimum use of the available capacity of control systems,

- studies and works necessary for the harmonisation of equipment and procedures, in such a way as to be able to integrate the various service providers, focusing on the guidelines set by the European Civil Aviation Conference (ECAC).

\section{Positioning and Navigation Network}

The Trans-European positioning and satellite navigation systems include positioning and navigation systems which in the future will be defined on the basis of the European Radio Navigation Plan. These systems will be able to provide reliable and efficient services for positioning and navigation systems to be used in all available modes of transport.

Projects of common interest will be deemed to be projects related to the creation of any component of the future European Radio Navigation Plan or of global satellite navigation and positioning forming a part of the following structure:

- control centres - including processing and control system,

- navigation ground station network,

- segments of the space in which they operate satellites which transmit beacons,

- network of surveillance stations.

12 http://www.ulc.gov.pl/index.php?option=com_content\&task=view\&id=322\&Itemid= 333, [05.02.2015]. 


\section{Funding of Trans-European Transport Network}

Funds from the budget of the Trans-European Transport Network are designed for projects of common interest and will:

- integrate all types of transport,

- contribute to the protection of the environment and the increase in safety standards,

- contribute to the sustainable development of transport networks across the European Union,

- ensure interoperability and coherence of the Trans-European Transport Network together with the improvement of access to it.

Projects of common interest are projects that satisfy the above mentioned tasks of the Trans-European Network concerning transport infrastructure or the aforementioned systems, corresponding to at least one of the above priorities, and that which is potentially viable. In the course of work on the project and its implementation, member states must take account of environmental issues by assessing the impact of the project on the environment.

As regards the scope of civil aviation as a priority project of the Trans-European Transport Network, it should consider ${ }^{13}$ :

- infrastructure to enable access to airport,

- development of airports - including terminals and runways,

- combination of airports with rail infrastructure,

- projects designed to protect the environment,

- issues related to the safety of air traffic,

- issues concerning security in air traffic.

Among the priority projects completed to date, only the aviation infrastructure at Malpensa Airport was finished (implementation was completed in 2001). Among the above mentioned 30 priority projects, there are no other civil aviation projects.

The issues related to financing the Trans-European Network are regulated by Regulation No 2236/95 laying down general rules for the granting of community

13 http://www.ulc.gov.pl/index.php?option=com_content\&task=view\&id=322\&Itemid= 333, [07.02.2015]. 
financial aid in the field of Trans-European Networks. According to this ordinance, as amended by Regulation No 1655/1999 and Regulation No 807/2004, community assistance may be granted only to projects of common interest and this can take one or more of the following forms:

- co-financing of studies related to projects, including preparatory, feasibility and evaluation studies, and technical support for these studies (up to $50 \%$ of the total cost of a study, except in exceptional cases),

- subsidising the interest on loans from the European Investment Bank or other public or private financial bodies,

- participation in fees for guarantees for loans from the European Investment Fund or other financial institutions,

- direct grants to investment in duly justified cases,

- participation in capital risk for investment funds or comparable financial undertakings with a priority focus on providing capital risk for projects in the field of Trans-European Networks involving substantial private sector investment - such capital risk participation shall not exceed $1 \%$ of the budget.

The existing development plans of the Trans-European Network for next year assumes the extension of the Trans-European Network in areas of the neighbouring countries of the European Union. Moreover, they include connecting the TransEuropean Network with the transport Network of Mediterranean countries MEDA project, aimed at creating a network of Euro-Mediterranean transport.

\section{Poland in Trans-European Transport Network}

The main objective of the Trans-European Transport Network in Poland is the improvement of Polish transport accessibility and interregional connections by developing the road and air Trans-European Transport Network and improving connections between the main cities of eastern Poland with the rest of the country though the development of the road network in this region.

Currently, ten Polish airports meet the conditions cited previously and, therefore, they are in the Trans-European Transport Network. Among these ports are the airports located at: Warszawa - Chopin Airport, Gdansk, Szczecin, Poznan, Katowice, Krakow, Rzeszow, Łódź, Bydgoszcz and Wroclaw (Picture 1). 
Poland has the opportunity to apply for project funding under the Trans-European Transport Network. Although all the above conditions must be met in order for the member states of the European Union to transfer funds for development projects.

Probably in the long term this will not create significant changes to the community guidelines on the Trans-European Transport Network, and in connection with the financial perspective for 2007-2013 changes in the rules to the Trans-European Transport Network funding after 2006 should be taken into account.

A priority is to increase the capacity of airports located in the Trans-European Transport Network and bandwidth in Polish airspace and to ensure a high standard of service ${ }^{14}$.

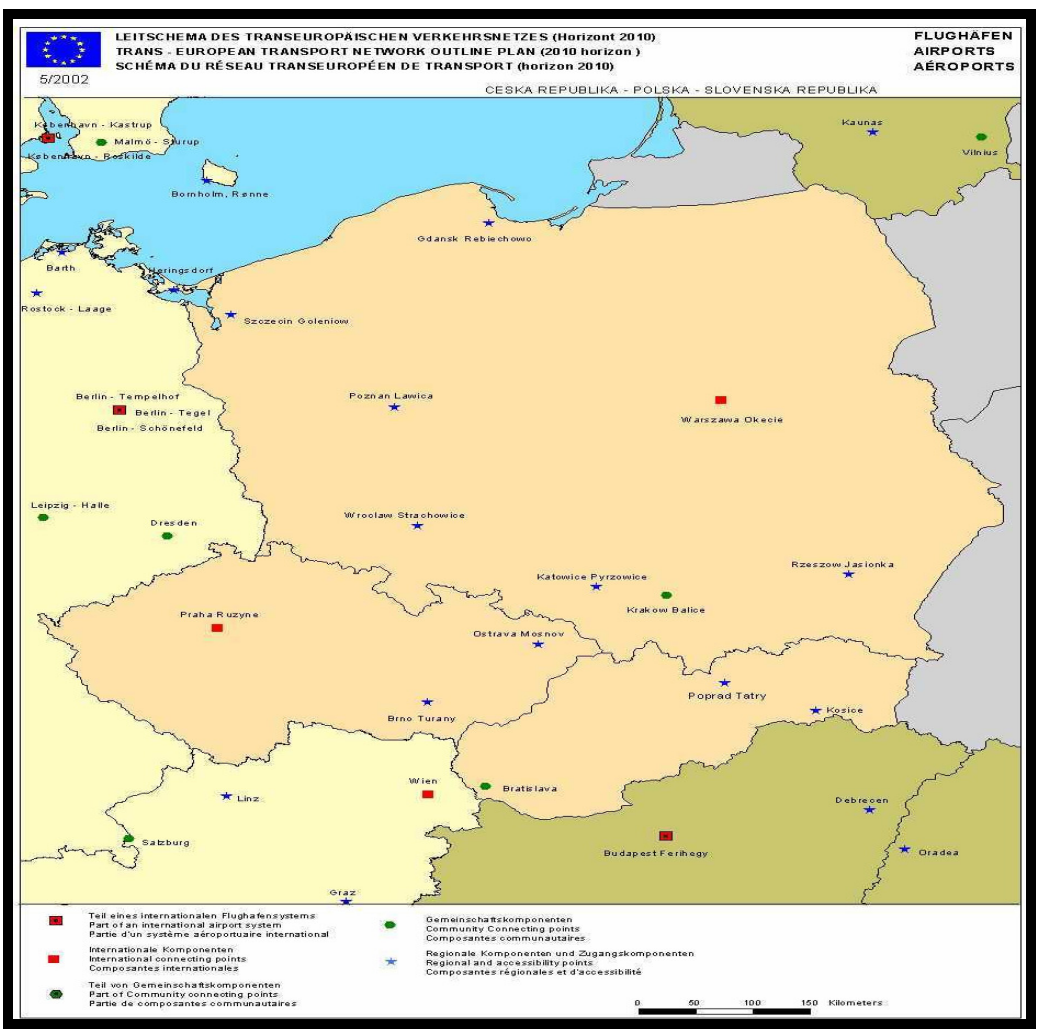

Source: Trans-European Transport Network.

Picture 1. Map of airports located in the Trans-European Transport Network including the airports located on Polish territory

14 http://www.pois.gov.pl/WstepDoFunduszyEuropejskich/Strony/6.aspx, [01.02.2015]. 
In the case of services provided, there should be no major objections, whereas in the case of airport capacity, there is a forecast according to which, if Poland does not take adequate steps, bandwidth will be completely exhausted. The spectrum bandwidth exhaustion is most threatening to Warsaw Chopin Airport because it is the largest airport in Poland and supports the largest number of passengers. According to forecasts, if appropriate steps are not taken bandwidth could be exhausted in the years 2020 - 2025. Some kind of salvation can be come from Warsaw's second airport - Modlin, although the weather conditions that prevail in the vicinity often make it impossible to conduct air operations.

There were plans for a Central Airport, although at the time Modlin airport opened it was expected that these plans would be postponed, if not completely rejected.

\section{Conclusion}

In summary, all of the above factors affect air transport in the Trans-European Transport Network. However, we should realise that the Trans-European Transport Network is not only an air network, but also a rail, road and marine network, if we are talking about transport.

Poland can greatly benefit from the funds allocated for the modernisation and construction of new airports, which may affect the air mobility of the citizens of our country. An additional advantage of the network development of airports in Poland can contribute to economic development, and to open up the world for Polish citizens abroad.

\section{Bibliography}

[1] Treaty of European Union.

[2] Treaty of Mastricht.

[3] http://europa eu/agencies/executive_agencies/ten-t/index_pl.htm.

[4] http://www.ulc.gov.pl/index.php?option=com_content\&task=view\&id=322\&Itemid=333.

[5] http://www.cie.gov.pl/HLP/files.nsf/0f93de09147035b3c1256ef5004250b8/ 782f3a4858c8d510c125733900445df2?OpenDocument.

[6] http://www.pois.gov.pl/ WstepDoFunduszyEuropejskich/Strony/6.aspx. 